\title{
Development, characterization and viability study of probiotic microcapsules produced by complex coacervation followed by freeze-drying
}

\section{Thaiane Marques da Silva ${ }^{1}$ (D) Juliano Smanioto Barin ${ }^{1}$ Eduardo Jacob Lopes $^{1}$ Alexandre José Cichoski ${ }^{1}$ Erico Marlon de Moraes Flores ${ }^{2}$ Cristiane de Bona da Silva ${ }^{3}$ Cristiano Ragagnin de Menezes $^{1^{*}}$ (iD)}

${ }^{1}$ Departamento de Ciência e Tecnologia de Alimentos, Universidade Federal de Santa Maria (UFSM), 97105-900, Santa Maria, RS, Brasil. E-mail: cristiano.ufsm@gmail.com. *Corresponding author.

${ }^{2}$ Departamento de Química, Universidade Federal de Santa Maria (UFSM), Santa Maria, RS, Brasil.

${ }^{3}$ Departamento de Farmácia, Universidade Federal de Santa Maria (UFSM), Santa Maria, RS, Brasil

ABSTRACT: Technique of complex coacervation was used to produce microcapsules of Lactobacillus acidophilus La-5 encapsulated in gelatin and gum arabic which were then freeze-drying. Microcapsules were characterized using scanning electron and optical microscopy, and resistance of probiotics was evaluated during release into a simulated gastrointestinal tract and storage at different temperatures. The complex coacervation process produced microcapsules with a high encapsulation efficiency (77.60\% and 87.53\%), ranging from 127.14-227.05 $\mu$ m with uniform distribution. Microencapsulation was an efficient approach to achieve significant protection of probiotics against simulated gastrointestinal conditions compared with free cells. Encapsulation also improved the viability of probiotics during storage at either - $18{ }^{\circ} \mathrm{C}$ for 120 days, $7{ }^{\circ} \mathrm{C}$ for 105 days or $25{ }^{\circ} \mathrm{C}$ for 45 days. Therefore, complex coacervation was demonstrated to be adequate and promising for encapsulation of probiotics.

Key words: microencapsulation, Lactobacillus acidophilus, gelatin, gum Arabic.

Desenvolvimento, caracterização e estudo da viabilidade de microcápsulas probióticas produzidas por coacervação complexa seguida de liofilização

RESUMO: A técnica de coacervação complexa foi utilizada para a produção de microcápsulas contendo Lactobacillus acidophilus La-5 em gelatina e goma arábica seguida de secagem por liofilização. As microcápsulas foram caracterizadas por microscopia óptica e eletrônica de varredura, assim como a resistência dos probióticos frente à liberação "in vitro" ao trato gastrointestinal simulado e ao armazenamento em diferentes condições de temperatura também foram avaliados. O processo de coacervação complexa formou microcápsulas com alta eficiência de encapsulação (77,60\% e 87,53\%), tamanho compreendido entre 127,14 e 227,05 um e distribuição uniforme. As microcápsulas foram eficientes em promover a proteção substancial dos probióticos frente às condições gastrointestinais simuladas, em comparação às células livres. A encapsulação também foi eficiente em manter a viabilidade dos probióticos durante o armazenamento em temperaturas de ${ }^{-} 18{ }^{\circ} \mathrm{C}$ por 120 dias, $7{ }^{\circ} \mathrm{C}$ por 105 dias e $25{ }^{\circ} \mathrm{C}$ por 45 dias. Dessa forma, a coacervação complexa se mostra adequada e promissora para a encapsulação dos probióticos.

Palavras-chave: microcápsulas, Lactobacillus acidophilus, coacervação complexa, liofilização.

\section{INTRODUCTION}

Probiotic cultures are becoming increasingly popular for use as adjuvants in food products due to their beneficial effects on human health. Lactobacillus acidophilus has attracted significant research interest due to its probiotic characteristics. Its health benefits include reduction of symptoms of lactose intolerance, inhibition of pathogenic microorganisms and reduction of cholesterol levels (OLIVEIRA, 2006).

However, studies have indicated that the survival and viability of probiotic bacteria in food products is often low, resulting in counts below $6 \log$ $\mathrm{CFU} \mathrm{g^{-1 }}$ which is the recommended daily intake for health benefits (FAO et al., 2001; SHOJI et al., 2013). Therefore, research into methods which improve the viability of bacteria and overall quality of probioticcontaining products is of high importance.

Microencapsulation has been employed to protect probiotic bacteria from adverse conditions in the external environment and the gastrointestinal tract; therefore, providing these bacteria in quantities that are sufficient for the realization of their beneficial effects, as well as improving their shelf life (CHÁVARRI et al., 2012; SHOJI et al., 2013). 
Coacervation has been used as a microencapsulation technique in a number of industries for a wide range of applications including pharmaceuticals, food products, chemicals, cosmetics and controlled release of various types of substances (ALVIM \& GROSSO, 2010). The complex coacervation technique presents several advantages compared to other encapsulation techniques; such as versatility, ease of operation, possible use of biopolymers, low cost, use of mild temperatures and absence of organic solvents (MARQUES DA SILVA et al., 2018). Moreover, it is a promising method with great potential for the encapsulation of probiotics; however, limited research has been carried out regarding the use of complex coacervation for this application (CHÁVARRI et al., 2012; SHOJI et al., 2013; MARQUES DA SILVA et al., 2018).

Given the above, the objective of this study was to microencapsulate Lactobacillus acidophilus La-5 using complex coacervation followed by freeze-drying, then characterize the particles and evaluate the viability and stability of the encapsulated culture during storage.

\section{MATERIALS AND METHODS}

Microencapsulation by the complex coacervation technique and freeze-drying process

Production of the microcapsules was performed according to the previously published methodology of MARQUES DA SILVA et al. (2018). The culture was added to $100 \mathrm{~mL}$ of $2.5 \%$ gelatin (Gelita, Eberbach, Germany), kept under stirring and heating $\left(48-50{ }^{\circ} \mathrm{C}\right)$. Then, $100 \mathrm{~mL}$ of $2.5 \%$ gum Arabic (CNI, São Paulo, Brazil) and 400 $\mathrm{mL}$ of sterile distilled water were added, and the $\mathrm{pH}$ was adjusted to 4.0. After this step, heating was turned off, allowing the culture to cool down until the temperature reached $10-12{ }^{\circ} \mathrm{C}$. The culture was allowed to settle and the coacervate was removed by filtration. A portion of the produced microcapsules was frozen $\left(-18{ }^{\circ} \mathrm{C}\right.$ for 24 hours) on the day of preparation. Microcapsules were freeze dried for 24 hours in a lyophilizer (L101, Liotop, Brazil) under the following conditions: vacuum of $0.2-0.3 \mu \mathrm{Hg}$ and condenser temperature of $-37^{\circ} \mathrm{C}$ ).

\section{Encapsulation efficiency}

The encapsulation efficiency (EE\%), was calculated for wet and dry microcapsules according to ANNAN et al. (2008) (Equation 1).

$\mathrm{EE}=\left(\mathrm{N} / \mathrm{N}_{0}\right) \times 100$

where $\mathrm{N}$ is the number of viable cells $\left(\log \mathrm{CFU} \mathrm{g^{-1 }}\right)$ released from the microcapsules and $\mathrm{N}_{0}$ is the number of viable cells $\left(\log \mathrm{CFU} \mathrm{g}{ }^{-1}\right)$ in the cell concentrate prior to microencapsulation.

Morphological characterization of microcapsules by optical and scanning electron microscopy

Optical microscopy was performed using a Scope A.1 optical microscope (Zeiss, Germany) equipped with an AxioCam MRc digital camera (Carl Zeiss) for wet capsules. The morphology of the dried microcapsules was evaluated using scanning electron microscopy (Sigma 300 VP, Zeiss).

\section{Evaluation of the mean diameter and distribution of microparticles size}

The mean sizes of wet and dry microparticles were measured using a Mastersizer 2000 (Malvern, Germany).

\section{Viable cell count}

Viable cell count was performed according to the methodology described by SHEU et al. (1993). Appropriate dilutions were prepared using peptone water and transferred in triplicate to sterile Petri dishes, followed by the addition of MRS broth (de Man, Rogosa, and Sharpe) and agar (Kasvi, Paraná, Brazil). Plates were incubated at $37^{\circ} \mathrm{C}$ for $72 \mathrm{~h}$ in anaerobic jars containing anaerobic generators (Anaerobac, Probac, São Paulo, Brazil). Dilutions of the microcapsules were prepared using $1 \mathrm{~g}$ of wet microcapsules or $0.1 \mathrm{~g}$ of dried microcapsules, followed by the addition of 9 $\mathrm{mL}$ sodium phosphate buffer solution ( $\mathrm{pH} 7.5)$. Results were expressed in $\log \mathrm{CFU} \mathrm{mL} \mathrm{m}^{-1}$.

To evaluate storage stability, microencapsulated probiotic cultures were stored at different temperatures; wet and dry microcapsules were stored at room temperature $\left(25^{\circ} \mathrm{C}\right)$, under refrigeration $\left(7{ }^{\circ} \mathrm{C}\right)$ or frozen $\left(-18{ }^{\circ} \mathrm{C}\right)$, for 120 days. Viable cell counts were performed as described above.

Survival of Lactobacillus acidophilus La-5 under in vitro simulated gastrointestinal conditions

Simulated gastrointestinal conditions were created according to the protocol of MADUREIRA et al. (2011), with some modifications. Aliquots of $2 \mathrm{~g}$ of wet microcapsules and $1 \mathrm{~g}$ of dry microcapsules were used. Analysis was carried out in a shaking refrigerated incubator (TE-421, Tecnal, Brazil) maintained at 37 ${ }^{\circ} \mathrm{C}$ to simulate body temperature, with mechanical shaking to simulate the peristaltic movements of each section of the digestive tract. The steps were as follows: stomach (90 minutes) with a solution of pepsin added in aliquots of $0.05 \mathrm{~mL} \mathrm{~L}^{-1}$, duodenum (20 minutes) 
with a solution of pancreatin and bile salts added in an aliquot of $0.25 \mathrm{~mL} \mathrm{~L}^{-1}$, and ileum (90 minutes) was brought about by an increase of $\mathrm{pH}$ to 6.5 using filtersterilized $0.1 \mathrm{M} \mathrm{NaHCO}_{3}$; after which, aliquots were removed to assess viable cell count.

\section{Statistical analysis}

Results were evaluated using analysis of variance (ANOVA) followed by Tukey's means comparison test at a level of $5 \%$ significance $(p<0.05)$. Statistica 7 software was used for all statistical analyses.

\section{RESULTS AND DISCUSSION}

\section{Encapsulation efficiency}

The encapsulation efficiencies achieved for Lactobacillus acidophilus La-5 microcapsules were $87.53 \% \pm 0.40$ and $77.60 \% \pm 0.75$ (mean \pm standard deviation) in their wet and dry forms, respectively. The difference may be explained by the formation of ice crystals during freeze-drying, which remove the bound water and may damage bacterial cell membranes and proteins, with consequent reduction of probiotic viability (SHOJI et al., 2013; CHEN et al., 2017). However, the high encapsulation efficiency values obtained in the present study indicated that complex coacervation is adequate for probiotics.

Our results agreed with those of HOLKEM et al. (2016), who reported the use of emulsification for encapsulation of Bifidobacterium lactis with an encapsulation efficiency of $89.71 \%$. However; in a study performed by ZOU et al. (2011), in which the authors produced alginate microspheres containing Bifidobacterium bifidum F-35 by emulsification/ internal gelation, the particles were strengthened by using a mixture including starch or pectin or by coating with chitosan or poly-l-lysine to provide additional protection. The authors achieved an encapsulation efficiency of $43-50 \%$.

Morphological characterization of microcapsules by optical and scanning electron microscopy

As figures $1 \mathrm{a}$ and $1 \mathrm{~b}$ illustrate, optical microscopy of wet microcapsules revealed that complex coacervation efficiently achieved

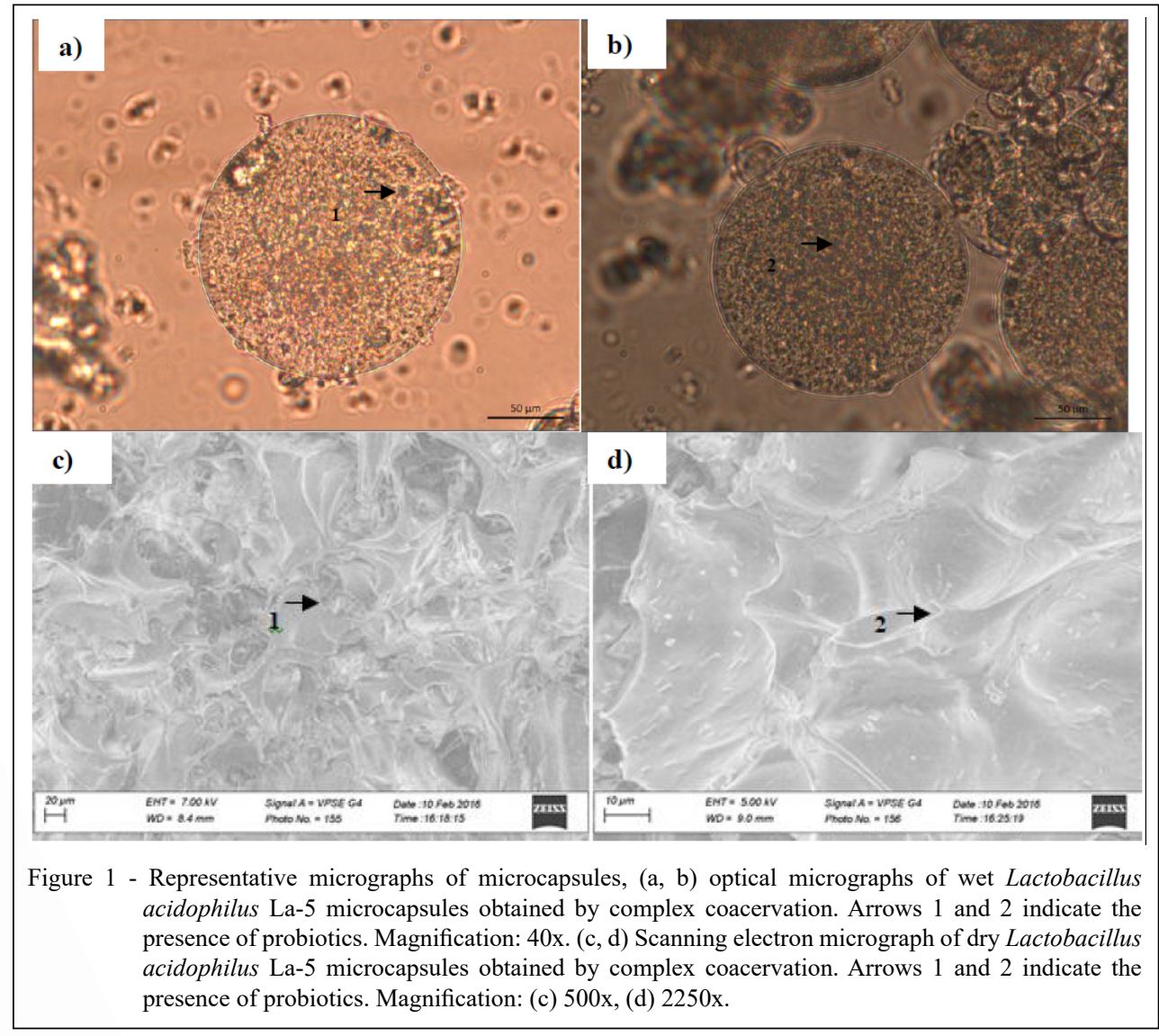

Ciência Rural, v.49, n.7, 2019. 
microencapsulation of L. acidophilus La-5, as the presence of microorganism inside the microcapsules can be observed. In addition, the microcapsules presented with rounded shapes and varied sizes, with homogeneous and multinuclear core distribution.

ETCHEPARE et al. (2016) encapsulated L. acidophilus La-14 in alginate using the extrusion method, and reported the presence of microorganisms inside the microcapsules, distributed in a multinuclear and homogeneous form. Similarly, COMUNIAN et al. (2013) encapsulated ascorbic acid via complex coacervation using gelatin and gum arabic as encapsulating materials, and observed similar results of rounded, multinucleated microcapsules, which confer greater core protection.

When observed by scanning electron microscopy (Figures 1c and 1d), the dry microcapsules were seen to form agglomerates, which - according to COMUNIAN et al. (2013) — is typical behavior of microcapsules that are produced by coacervation and subsequently freeze-dried. Similar results were also observed by OLIVEIRA et al. (2007).

\section{Mean diameter and size distribution of the microparticles}

The mean diameter of the wetmicrocapsules was $127.14 \mu \mathrm{m}$. This is in line with our expectations, since probiotic microcapsules are generally around $100 \mu \mathrm{m}$ in diameter. A study carried out by ALVIM \& GROSSO (2010) reported that when paprika oleoresin was encapsulated in gelatin and gum arabic by complex coacervation, the mean diameter was about $96.4 \mu \mathrm{m}$. In contrast, CHITPRASERT et al. (2012) demonstrated that encapsulation of $L$. reuteri KUB-AC5 in aluminum carboxymethyl celluloserice bran by emulsion resulted in observed mean diameters varying between 159.52 and $661.19 \mu \mathrm{m}$.

The mean diameter of the dry microcapsules was $227.05 \mu \mathrm{m}$. This is increased compared with the wet microcapsules, which can be explained by the formation of agglomerates during the freeze drying. According to OLIVEIRA et al. (2007), high mean diameters and large variations in measured particle size are due to the adhesion of encapsulating materials, which causes formation of agglomerates.

Therefore, these results indicated that the mean diameter of microcapsules depends on the microencapsulation technique, encapsulating materials, and processing conditions (ABEDIN, 2014). Moreover, it is important to notice that, in relation to sensory properties and addition of probiotics encapsulated in food, the microcapsules should have sizes between 100 and $200 \mu \mathrm{m}$ (LAWLESS \& HEYMANN, 2010).

\section{Survival of Lactobacillus acidophilus La-5 under in} vitro simulated gastrointestinal conditions.

Resultsofthesurvivalofthemicroorganisms under simulated gastrointestinal conditions are shown in table 1. It is immediately clear that both free and microencapsulated probiotics lost viability in this experiment. However, microencapsulation offered greater protection to probiotics as a smaller decrease in viability was observed. These results agree with those of MOUMITA et al. (2016) who observed viable cell counts of $2.06 \log \mathrm{CFU} \mathrm{g} \mathrm{g}^{-1}$ after exposing L. acidophilus encapsulated in sodium alginate by extrusion to the simulated gastrointestinal tract.

Taken together, the result of the present study and previously published investigations confirmed that encapsulation protects probiotics from conditions of stress; however, the degree of protection depends on the type of bacteria (MOUMITA et al., 2016). Moreover, when microbial cells are exposed to some chemicals such as acids, bases, or surfactants; physicochemical and physiological changes may occur, causing cell deactivation by rupturing the cell membrane, denaturation of proteins and nucleic acids, and disruption of key biochemical pathways.

Table 1 - Viability of wet and dry L. acidophilus La-5 microcapsules obtained by complex coacervation during the resistance test to in vitro simulated gastrointestinal conditions.

\begin{tabular}{lccr}
\hline Treatment & La-5 free $\left(\log\right.$ CFU.g $\left.{ }^{-1}\right)$ & La-5 wet $\left(\log\right.$ CFU.g $\left.{ }^{-1}\right)$ & La-5 dry $(\log$ CFU.g \\
\hline Initial & $9.89 \pm 0.10^{\mathrm{A}}$ & $8.42 \pm 0.02^{\mathrm{A}}$ & $6.17 \pm 0.11^{\mathrm{A}}$ \\
Stomach & $5.12 \pm 0.19^{\mathrm{B}}$ & $5.21 \pm 0.18^{\mathrm{B}}$ & $4.46 \pm 0.02^{\mathrm{B}}$ \\
Duodenum & $3.94 \pm 0.04^{\mathrm{C}}$ & $4.70 \pm 0.02^{\mathrm{C}}$ & $4.30 \pm 0.01^{\mathrm{C}}$ \\
Ileum & $2.56 \pm 0.07^{\mathrm{D}}$ & $3.33 \pm 0.14^{\mathrm{D}}$ & $3.94 \pm 0.15^{\mathrm{D}}$ \\
\hline
\end{tabular}

Means followed by the same uppercase letters do not differ statistically in column by the Tukey test at 5\% significance. Means obtained in triplicate. 
Thus, protection may occur through a number of mechanisms and will; therefore, depend on the properties of microgel (YAO et al., 2017). For example, the local $\mathrm{pH}$, ionic strength, and osmotic pressure within the microgel may increase the stability of proteins and nucleic acids, leading to an increase in the thermal denaturation temperature. In this sense, it should be noted that gelatin is a protein with protective properties, as it can function as a buffer. Furthermore, the biopolymer network of the microgel can prevent disruptive molecules (such as bile salts and enzymes) from reaching the encapsulated cells. The response of probiotics to environmental stresses is also altered due to their high concentration inside the microcapsules, which affects the signaling between neighboring microbial cells.

ETCHEPARE et al. (2016) encapsulated L. acidophilus by extrusion using alginate as the encapsulating material and observed the wet microcapsules to have a viable cell count of $4.14 \mathrm{log}$ $\mathrm{CFU} \mathrm{g}{ }^{-1}$ in the simulated stomach conditions and 6.11 $\log$ CFU g ${ }^{-1}$ in the simulated ileum (final step). Dry microcapsules presented a viable cell count of 3.92 $\log$ CFU g ${ }^{-1}$ in the simulated stomach and $5.41 \mathrm{log}$ $\mathrm{CFU} \mathrm{g}{ }^{-1}$ in the simulated ileum.
Therefore, we can conclude that microencapsulation by complex coacervation protected the microorganisms from the adverse conditions of the gastrointestinal tract; although, viable cell count is below the daily recommended intake (FAO et al., 2001; SHOJI et al., 2013). The viability of $L$. acidophilus under simulated gastrointestinal conditions will depend on the microencapsulation technique, as well as the processing conditions and condition of the microcapsules (wet or dry) (FAO et al., 2001).

Viability of microencapsulated probiotic cultures during storage at different temperatures

The viability of $L$. acidophilus following storage at $-18,7$, and $25^{\circ} \mathrm{C}$ for different storage times are presented in table 2 . At room temperature $\left(25^{\circ} \mathrm{C}\right.$ ), wet microcapsules were viable (defined as $>6 \log$ CFU g ${ }^{-1}$ ) for 15 days, with a cell count of $6.27 \log \mathrm{CFU} \mathrm{g}^{-1}$ at this time point. In the dry form, microcapsules were viable for 45 days, with a cell count of $6.13 \log \mathrm{CFU} \mathrm{g}{ }^{-1}$ at this time point. During refrigeration $\left(7^{\circ} \mathrm{C}\right)$, the wet and dry microcapsules were viable for 30 days $\left(6.08 \log \mathrm{CFU} \mathrm{g} \mathrm{g}^{-1}\right)$ and 105 days $\left(6.59 \mathrm{CFU} \mathrm{g}^{-1}\right)$, respectively. These

Table 2 - Viability of wet and dry L. acidophilus La-5 microcapsules obtained by complex coacervation during 120 days of storage at different temperatures.

\begin{tabular}{lccc}
\hline Treatment & $25^{\circ} \mathrm{C}$ & $-18^{\circ} \mathrm{C}$ & $7^{\circ} \mathrm{C}$ \\
\hline Time (days) & $9.92 \pm 0.05^{\mathrm{Aa}}$ & $9.92 \pm 0.05^{\mathrm{Aa}}$ & $9.92 \pm 0.05^{\mathrm{Aa}}$ \\
0 & $6.27 \pm 0.15^{\mathrm{Bc}}$ & $7.50 \pm 0.29^{\mathrm{Bb}}$ & $7.73 \pm 0.05^{\mathrm{Ba}}$ \\
15 & $5.02 \pm 0.06^{\mathrm{Cc}}$ & $7.75 \pm 0.07^{\mathrm{Ba}}$ & $6.08 \pm 0.04^{\mathrm{Db}}$ \\
30 & $5.89 \pm 0.36^{\mathrm{Cb}}$ & $6.85 \pm 0.06^{\mathrm{Ca}}$ & $5.27 \pm 0.01^{\mathrm{Ec}}$ \\
45 & $5.74 \pm 0.15^{\mathrm{BCb}}$ & $6.57 \pm 0.16^{\mathrm{CDa}}$ & $3.46 \pm 0.17^{\mathrm{Gc}}$ \\
60 & $5.99 \pm 0.23^{\mathrm{Bb}}$ & $7.58 \pm 0.17^{\mathrm{Ba}}$ & $5.02 \pm 0.04^{\mathrm{Fc}}$ \\
75 & $5.20 \pm 0.18^{\mathrm{Cb}}$ & $6.92 \pm 0.08^{\mathrm{Ca}}$ & $5.08 \pm 0.06^{\mathrm{EFb}}$ \\
90 & $5.04 \pm 0.25^{\mathrm{Cb}}$ & $7.48 \pm 0.17^{\mathrm{Ba}}$ & $5.18 \pm 0.06^{\mathrm{EFb}}$ \\
105 & $4.02 \pm 0.06^{\mathrm{Db}}$ & $6.29 \pm 0.02^{\mathrm{Da}}$ & $6.41 \pm 0.14^{\mathrm{Ca}}$ \\
120 & $8.80 \pm 0.08^{\mathrm{Aa}}$ & $8.80 \pm 0.08^{\mathrm{Aa}}$ & $8.80 \pm 0.08^{\mathrm{Aa}}$ \\
\hline 0 & $8.06 \pm 0.18^{\mathrm{ABb}}$ & $8.89 \pm 0.14^{\mathrm{Aa}}$ & $8.19 \pm 0.12^{\mathrm{Bb}}$ \\
15 & $7.88 \pm 0.11^{\mathrm{Bb}}$ & $8.76 \pm 0.20^{\mathrm{Aa}}$ & $7.71 \pm 0.16^{\mathrm{Bb}}$ \\
30 & $6.13 \pm 0.22^{\mathrm{Cb}}$ & $7.90 \pm 0.15^{\mathrm{Ba}}$ & $6.91 \pm 0.23^{\mathrm{Cb}}$ \\
45 & $5.84 \pm 0.12^{\mathrm{Cb}}$ & $6.97 \pm 0.17^{\mathrm{Ca}}$ & $6.90 \pm 0.15^{\mathrm{Ca}}$ \\
75 & $5.82 \pm 0.12^{\mathrm{Cb}}$ & $6.91 \pm 0.01^{\mathrm{Ca}}$ & $6.84 \pm 0.27^{\mathrm{Ca}}$ \\
90 & $5.75 \pm 0.18^{\mathrm{Cb}}$ & $6.76 \pm 0.23^{\mathrm{Ca}}$ & $6.71 \pm 0.28^{\mathrm{Ca}}$ \\
105 & $5.46 \pm 0.45^{\mathrm{Cb}}$ & $6.62 \pm 0.24^{\mathrm{CDa}}$ & $6.59 \pm 0.11^{\mathrm{Ca}}$ \\
\hline
\end{tabular}

Means followed by the same uppercase letters in column and lowercase in line do not differ statistically by the Tukey test at $5 \%$ significance. Means obtained in triplicate. 
results corroborated those of PEDROSO et al. (2012), who encapsulated L. acidophilus in lipid matrices by spray chilling and observed that the microcapsules were viable for up to 30 days of storage at $7{ }^{\circ} \mathrm{C}$. Similarly, OLIVEIRA et al. (2007) demonstrated that encapsulation of $L$. acidophilus by complex coacervation followed by spouted-bed drying using pectin and casein as encapsulating materials resulted in viable cell counts of $8.18 \mathrm{log}$ CFU g- ${ }^{1}$ after 90 days at $7{ }^{\circ} \mathrm{C}$. Results obtained in the present study emphasized the importance of optimizing the encapsulation technique in order to protect probiotics.

During freezing at $-18{ }^{\circ} \mathrm{C}$, both the wet and dry microcapsules were viable for 120 days with cell counts of $6.29 \log \mathrm{CFU} \mathrm{g}{ }^{-1}$ and $6.15 \mathrm{log}$ CFU g ${ }^{-1}$, respectively. According to OLIVEIRA et al. (2007), bacterial stability during storage increases as storage temperature decreases, which was observed in the present study. These results are also in accordance with those of ETCHEPARE et al. (2016), who reported that alginate microcapsules of $L$. acidophilus produced by extrusion were viable for 135 days and 60 days in the wet and dry forms, respectively; with viable cell counts of 6.35 $\log$ CFU g ${ }^{-1}$ and $6.08 \log \mathrm{CFU} \mathrm{g}^{-1}$ for the wet and dry microcapsules, respectively.

The present study demonstrated that complex coacervation maintains the viability of $L$. acidophilus and provides an efficient approach to protect the microorganisms against temperature and long-term storage. Storage at freezing conditions $\left(-18^{\circ} \mathrm{C}\right)$ appears to be more appropriate, as it resulted in higher viable cell counts over a longer period of time compared with other techniques in the present study.

\section{CONCLUSIONS}

Complex coacervation proved to be suitable for the encapsulation of $L$. acidophilus because a high encapsulation efficiency was observed, as well as protection of the microorganisms in different conditions of $\mathrm{pH}$, temperature, and over long periods of time. Compared to other techniques, complex coacervation offers a number of advantages including high encapsulation efficiencies, versatility, and ease of operation. In the present study, the technique yielded higher encapsulation efficiencies than have been previously published. This highlighted the efficiency of complex coacervation, and its applicability to probiotic culture encapsulation.

\section{ACKNOWLEDGMENTS}

This study was financed in part by the Coordenação de Aperfeiçoamento de Pessoal de Nível Superior - Brasil (CAPES) - Finance Code 001".

\section{DECLARATION OF CONFLICT OF INTERESTS}

The authors declare no conflict of interest. The founding sponsors had no role in the design of the study; in the collection, analyses, or interpretation of data; in the writing of the manuscript, and in the decision to publish the results.

\section{AUTHORS' CONTRIBUTIONS}

The authors contributed equally to the manuscript.

\section{REFERENCES}

ABEDIN, R. Effect of process mixing on the size distribution and mean diameter of the thiol-triacrylate microcapsules. 2014. 74f. Dissertação (Mestrado em Engenharia Química) - Faculdade de Pós-Graduação da Universidade Estadual da Louisiana e Faculdade Agrícola e Mecânica, Universidade Estadual da Louisiana.

ALVIM, I. D.; GROSSO, C. R. F. Microparticles obtained by complex coacervation: influence of the type of reticulation and the drying process on the release of the core material. Ciência e Tecnologia de Alimentos, v.30, p.1069-1076, 2010. Available from: <http://www.scielo.br/scielo.php?script=sci arttext\&pid $=$ S0101-20612010000400036 $>$. Accessed: Oct. 30, 2017. doi: 10.1590/S0101-20612010000400036.

ANNAN, N. T. et al. Encapsulation in alginate-coated gelatin microspheres improves survival of the probiotic Bifidobacterium adolescentis $15703 \mathrm{~T}$ during exposure to simulated gastro-intestinal conditions. Food Research International, v.41, p.184-193, 2008. Available from: $<$ https://www.sciencedirect.com/science/article/pii/ S0963996907001937>. Accessed: Nov. 25, 2017. doi: 10.1016/j.foodres.2007.11.001.

CHÁVARRI, M. et al. Encapsulation technology to protect probiotic bacteria. Intech, v.23, p.501-539, 2012. Available from: <https://www.researchgate.net/publication/233540980 Encapsulation_Technology_to_Protect_Probiotic_Bacteria $>$. Accessed: Nov. 19, 2017. doi: $1 \overline{0} .5772 / 50046$.

CHEN, H -Y. et al. Microencapsulation of Lactobacillus bulgaricus and survival assays under simulated gastrointestinal conditions. Journal of Functional Foods, v.29, p.248-255, 2017. Available: <https://www.sciencedirect.com/science/ article/pii/S1756464616304042>. Accessed: Dec. 5, 2017. doi: 10.1016/j.jff.2016.12.015.

CHITPRASERT, P. et al. Aluminum carboxymethyl cellulose-rice bran microcapsules: Enhancing survival of Lactobacillus reuteri KUB-AC5. Carbohydrate Polymers, v.90, p.78-86, 2012. Available from: <https://www.sciencedirect.com/science/article/ pii/S0144861712004171>. Accessed: Dec. 2, 2017. doi: 10.1016/j. carbpol.2012.04.065. 
COMUNIAN, T. A. et al. Microencapsulation of ascorbic acid by complex coacervation: Protection and controlled release. Food Research International, v.52, p.373-379, 2013. Available from: $<$ https://www. sciencedirect.com/science/article/pii/S0963996913001919>. Accessed: Oct. 21, 2017. doi: 10.1016/j.foodres.2013.03.028.

ETCHEPARE, M. A. et al. Effect of resistant starch and chitosan on survival of Lactobacillus acidophilus microencapsulated with sodium alginate. LWT - Food Science and Technology, v.65, p.511-517, 2016. Available from: <https://www.sciencedirect. com/science/article/pii/S002364381530133X $>$. Accessed: Oct. 21 , 2017. doi: 10.1016/j.lwt.2015.08.039.

FAO - FOOD AND AGRICULTURE ORGANIZATION OF THE UNITED NATIONS et al. Probiotics in food: Health and nutritional properties and guidelines for evaluation. Córdoba: FAO Food and Nutrition Paper, 56p, 2001.

HOLKEM, A. T. et al. Development and characterization of alginate microcapsules containing Bifidobacterium BB-12 produced by emulsification/internal gelation followed by freeze drying. LWT - Food Science and Technology, v.71, p.302-308, 2016. Available from: <https://www.sciencedirect.com/science/ article/pii/S0023643816301967?via\%3Dihub>. Accessed: Dec. 5, 2017. doi: 10.1016/j.lwt.2016.04.012.

LAWLESS, H. T. \& HEYMANN, H. Sensory evaluation of food: Principles and practices. New York: Springer-Verlag, 2010. 2 ed.

MADUREIRA, A. R. et al. Protective effect of whey cheese matrix on probiotic strains exposed to simulated gastrointestinal conditions. Food Research International, v.44, p.465-470, 2011. Available from: <https://www.sciencedirect.com/science/ article/pii/S0963996910003182>. Accessed: Nov. 25, 2017. doi: 10.1016/j.foodres.2010.09.010.

MARQUES DA SILVA et al. Development and characterization of microcapsules containing Bifidobacterium $\mathrm{Bb}-12$ produced by complex coacervation followed by freeze drying. LWT - Food Science and Technology, v.44, p.465-470, 2018 Available from: <https://www.sciencedirect.com/science/ article/pii/S0023643817309519?via\%3Dihub>. Accessed: Apr. 02, 2018. doi: 10.1016/j.1wt.2017.12.057.

MOUMITA, S. et al. Evaluation of the viability of free and encapsulated lactic acid bacteria using in vitro gastro intestinal model and post storage survivability studies of symbiotic microcapsules in dry food matrix. LWT - Food Science and Technology v.77, p.460-467, 2016. Available from: <https://www.sciencedirect.
com/science/article/pii/S0023643816307666?via\%3Dihub>. Accessed: Oct. 21, 2017. doi: 10.1016/j.1wt.2016.11.079.

OLIVEIRA, A. C. J. Viabilidade de Lactobacillus acidophilus e Bifidobacterium lactis microencapsulados por coacervação, seguida de secagem por spray-drying e leito de jorro. 2006. 77f. Dissertação (Mestrado em Ciências Farmacêuticas) - Curso de PósGraduação em Ciências Farmacêuticas, Universidade de São Paulo.

OLIVEIRA, A. C. et al. Microencapsulation of B. lactis (B1 01) and L. acidophilus (LAC 4) by complex coacervation followed by spouted-bed drying. Drying Technology, v.25, p.1687-1693, 2007. Available from: <https://www.tandfonline.com/doi/ abs/10.1080/07373930701590939>. Accessed: Dec. 2, 2017. doi: $10.1080 / 07373930701590939$.

PEDROSO, D. D. L. et al. Protection of Bifidobacterium lactis and Lactobacillus acidophilus by microencapsulation using spray-chilling. International Dairy Journal, v.26, p.127-132, 2012. Available from: <https://www.sciencedirect.com/science/ article/pii/S0958694612001021>. Accessed: Oct. 20, 2017. doi: 10.1016/j.idairyj.2012.04.008

SHEU, T. Y. et al. Improving survival of culture bacteria in frozen desserts by microentrapment. Journal of Dairy Science, v.76, p.1902-1907, 1993. Available from: <https://www.sciencedirect. com/science/article/pii/S0022030293775232>. Accessed: Oct. 18, 2017. doi: 10.3168/jds.S0022-0302(93)77523-2.

SHOJI, A. S. et al. Viability of L. acidophilus microcapsules and their application to buffalo milk yoghurt. Food and Bioproducts Processing, v.91, p.83-88, 2013. Available: $<$ https://www.sciencedirect.com/science/article/pii/ S0960308512000697>. Accessed: Nov. 19, 2017. doi: 10.1016/j.fbp.2012.08.009.

YAO, M. et al. Microencapsulation of Lactobacillus salivarious Li01 for enhanced storage viability and targeted delivery to gut microbiota. Food Hydrocolloids, v.72, p.228-236, 2017. Available from: $<$ https:// www.researchgate.net/publication/317269858_Microencapsulation of Lactobacillus salivarious Li01 for enhanced storage viability and targeted delivery to gut microbiota\#pf9>. Accessed: Dec. 02, 2017. doi: 10.1016/j.foodhyd.2017.05.033.

ZOU, Q. et al. Microencapsulation of Bifidobacterium bifidum F-35 in reinforced alginate microspheres prepared by emulsification/internal gelation. International Journal of Food Science \& Technology, v.46, p.1672-1678, 2011. Available: <https://onlinelibrary.wiley. com/doi/abs/10.1111/j.1365-2621.2011.02685.x>. Accessed: Dec. 5, 2017. doi: $10.1111 / \mathrm{j} .1365-2621.2011 .02685 . x$. 